\title{
An Evaluation of Four Different Luminescence Immunoassay Systems: CELIA (chemiluminescent immunoassay), SPALT (solid-phase antigen luminescence technique), ILMA (immunoluminometric assay) and ILSA (immunoluminometric labelled second antibody)
}

A critical study of macro solid phases for use in immunoassay systems, Part III ${ }^{1}$ )

By W. G. Wood, H. Fricke, J. Haritz, A. Gadow, Heidi-Susanne Krausz, Bettina Tode, C. J. Strasburger and P.C. Scriba

Klinische Laboratorien, Klinik für Innere Medizin (Direktor: Prof. Dr. P. C. Scriba) Medizinische Hochschule Lübeck

(Received June 7/December 19, 1983)

Summary: The performance of different solid-phase luminescence immunoassays has been documented using four different assay concepts. These are CELIA (chemiluminescence immunoassay), SPALT (solid-phase antigen luminescence technique), ILMA (immunoluminometric assay) and ILSA (immunoluminometric labelled second-antibody assay). CELIA is analogous to a solid-phase radioimmunoassay and uses a labelled antigen, SPALT and ILSA use a labelled second (species-specific) antibody and ILMA a labelled substancespecific antibody, i.e. analogous to the immunoradiometric assay. Both bioluminescent and chemiluminescent labels have been used. Pyruvate kinase was used for bioluminescence and diazoluminol and N-(4-aminobutyl)-N-ethyl isoluminol hemisuccinamide for chemiluminescence. Relevant quality-control parameters and reference ranges have been given for the optimised assays. Assays described are: thyroxine, thyroxine binding globulin, cortisol, caeruloplasmin, ferritin and C-reactive protein.

Luminescence immunoassays with coefficients of variation comparable with radioimmunoassay have been designed, values of under $5 \%$ being obtainable within the working range of the assay.

\section{Beurteilung von vier verschiedenen Lumineszenz=Immunoassays: \\ CELIA (chemiluminescent immunoassay), \\ SPALT (solid-phase antigen luminescence technique), \\ ILMA (immunoluminometric assay) und \\ ILSA (immunoluminometric labelled second antibody).}

Eine kritische Untersuchung von Makro-Festphasen zum Gebrauch in Immunoassay-Systemen, Teil III ${ }^{1}$ )

Zusammenfassung: Die Entwicklung und Durchführung von Lumineszenzimmunoassays werden am Beispiel von vier verschchiedenen Assaykonzepten aufgezeigt. Der CELIA (Chemilumineszenzimmunoassay) verwendet markiertes Antigen, SPALT. (Solid-Phase Antigen Luminescence Technique) and ILSA (Immunoluminometric Labelled Second-Antibody Assay) markierten spezies-spezifischen „zweiten“ Antikörper und der ILMA (Immunoluminometric Assay) substanz-spezifischen Antikörper, die markiert sind. Sowohl Biolumineszenz (Pyruvatkinase)- als auch Chemilumineszenz (Diazoluminol und N-(4-Aminobutyl)-N-ethyl-isolu-

') Part I: J. Clin. Chem. Clin. Biochem. 21, 789-787. Part II: J. Clin. Chem. Clin. Biochem. 22, $337-347$. 
minol-hemisuccinamid)-Markierungen wurden verwendet und gegenübergestellt. QualitätskontrollkenngröBen und Referenzbereiche im Serum werden für die optimierten Assays ermittelt. Es werden Lumineszenzimmunoassays für die folgenden Substanzen beschrieben: Thyroxin, thyroxin-bindendes Globulin, Cortisol, Ferritin, Caeruloplasmin und C-reactives Protein.

Die entwickelten Lumineszenzimmunoassays zeigen dem Radioimmunoassay vergleichbare,Variationskoeffizienten mit Werten unter $5 \%$ im relevanten Bereich.

\section{Introduction}

This third and final part of a study upon solid phases for immunoassay describes the assays which have been developed from the experiments described in the first two parts $(1,2)$. Both functional and nonfunctional assay systems have been presented as well as comparisons between different assay systems for the same analyte.

The assays described include those using labelled antigens and labelled first or second antibodies. The labels used are: diazoluminol and N-(4-aminobutyl)$\mathrm{N}$-ethyl isoluminol hemisuccinamide, the latter being coupled via an active ester of $\mathrm{N}$-hydroxysuccinamide. The synthesis of the labels has already been described (2). The assays represent different analytes (haptens or peptides) and methods. Where applicable, assays which have already been introduced into the routine laboratory are presented with relevant quality-control parameters and comparisons with the methods which they have replaced.

\section{Materials and Methods \\ Materials \\ Antibodies}

Antibodies to human liver and spleen ferritins were purchased from Atlanta (Pelfreez), Heidelberg; Proma (Seward), Augsburg; Boehringer-Ingelheim (DAKO), Ingelheim; these being the distributors in the FRG. Antibodies to human C-reactive protein and human thyroxine binding globulin were obtained from Proma and Boehringer-Ingelheim.

Antibodies to caeruloplasmin were purchased from Behringwerke, Marburg a.d.L., FRG, whereas those for cortisol and thyroxine were donations from Dr. Mario Pazzagli, Firenze, Italy and the Fa. Henning Berlin GmbH respectively.

Donkey anti-rabbit IgG was purchased from Wellcome Diagnostika, Burgwedel, FRG and rabbit anti-sheep IgG from Boehringer Ingelheim.

\section{Standard materials}

Ferritin standards were obtained from Travenol-Clinical Assays, Munich, FRG, C-reactive protein serum standard from Behringwerke, thyroxine and cortisol standards from Henning Berlin and Diagnostic Products Corporation (Hermann Biermann, Bad Nauheim, FRG) respectively. Human transferrin was purchased from Behringwerke, human caeruloplasmin from Serva, Heidelberg, FRG or Sigma, Munich, human thyroxine binding globulin being a gift from Prof. K. Horn and Dr. R. Gärtner, Munich.

\section{Equipment}

The luminometers used were either the LKB-1251 (LKB Instruments, Gräfelfing, FRG) or the LB-950 (Laboratorium Prof. Dr. Berthold, Wildbad, FRG). The LKB-1251 was a 25-sample semiautomatic instrument with microprocessor, the LB-950 had a 300 sample capacity and was also microprocessor controlled. Both instruments were at the time of the experiments not able to process data fully so that an off-line data-processing with a desk-top computer (CBM 8032 - Commodore Business Machines, Neu-İsenburg, FRG) and spline function programme was necessary.

\section{Methods}

\section{CELIA - chemiluminescent immunoassay}

This type of assay is analogous to a solid-phase radioimmunoassay in which the first antibody was coupled to a polystyrene ball (1) and in which the tracer was an antigen labelled with $\mathrm{N}$-(4-aminobutyl)- $\mathrm{N}$-ethyl isoluminol hemisuccinamide instead of a radioactive marker. Table 1 shows the assay flow sheet for a TBG CELIA.

Tab. 1. Thyroxine binding globulin CELIA flow sheet.

$50 \mu$ l sample or standard

$200 \mu \mathrm{l}$ assay buffer $(0.05 \mathrm{~mol} / \mathrm{l}$ Tris- $\mathrm{HCl}$

containing $2.50 \mathrm{~g} / \mathrm{l}$ bovine serum albumin, $\mathrm{pH} 7.4$

1 sheep anti human TBG coated ball

Incubate at ambient temperature for $30 \mathrm{~min}$

$50 \mu \mathrm{l}$ diazoluminol labelled TBG (1:100 dilution*)

Incubate as above and wash with $2 \times 1 \mathrm{ml} 0.15 \mathrm{~mol} / \mathrm{l} \mathrm{NaCl}$ containing $0.15 \mathrm{ml} / 1$ Tween 20 .

Transfer balls to measuring cuvettes and load luminometer. The light initiation step is identical with that shown in table 2.

* The diazotisation was analogous to the method described in l.c. (2), replacing the second antibody with thyroxine binding globulin. The dilution factor given here is the further dilution of the TBG-diazoluminol. The amount of label added to each tube was approximately $100 \mathrm{ng}$.

\section{ILMA - immunoluminometric assay}

The ILMA is analogous to the IRMA (immunoradiometric assay) (3) and is especially suited for assays where the antigen is either unavailable or prohibitively expensive so that a SPALT (see below) assay is out of the question. Several antibody-pairs were tested until a suitable combination was found. Table 2 shows an assay flow sheet for a ferritin ILMA.

\section{ILSA - immunoluminometric labelled second-antibody assay}

The ILSA is identical with the ILMA, but with one exception, and that is that a labelled second antibody is used in addition to the two substance-specific antibodies used in the ILMA. This assay was only used in cases where diazoluminol was used for labelling the antibodies, in order to achieve maximal sensitivity. Table 3 shows a flow sheet for a C-reactive protein ILSA. 
Tab. 2. Ferritin ILMA flow sheet.

$20 \mu$ sample or standard

$200 \mu \mathrm{l}$ assay buffer $(0.025 \mathrm{~mol} / 1$ phosphate $/ 0.025 \mathrm{~mol} / \mathrm{l} \mathrm{Tris}-\mathrm{HCl}$ containing $0.5 \mathrm{ml} / /$ Tween 20 and $1.25 \mathrm{~g} / \mathrm{l}$ bovine serum albumin, $\mathrm{pH} 7.4$

1 goat anti human liver ferritin coated ball

Incubate for $3 \mathrm{~h}$ on a horizontal rotator $\left(180 \mathrm{~min}^{-1}\right)$

Wash with $2 \times 5 \mathrm{ml} 0.15 \mathrm{~mol} / 1 \mathrm{NaCl}$ containing $0.15 \mathrm{ml} / \mathrm{l}$ Tween 20

$200 \mu \mathrm{l}$-(4-aminobutyl)-N-ethylisoluminol hemisuccinamide labelled rabbit anti human ferritin (1:500 dilution)*

Incubate and wash as above and transfer balls to measuring cuvettes.

Add $250 \mu \mathrm{l} 0.15 \mathrm{~mol} / \mathrm{l} \mathrm{NaCl}$ and load luminometer. Initiate light reaction with $1 \mathrm{~mol} / 1 \mathrm{NaOH}, 2 \mathrm{mg} / 1$ microperoxidase-MP 11 and $0.15 \mathrm{~mol} / \mathrm{l} \mathrm{H}_{2} \mathrm{O}_{2}(100 \mu \mathrm{l}+10 \mu \mathrm{l}+360 \mu \mathrm{l}$ respectively).

Integrate the light signal over $20 \mathrm{~s}$

* This represents the dilution of the labelled antibody after coupling to $\mathrm{N}$-(4-aminobutyl)-N-ethylisoluminol hemisuccinamide using the same method for labelling donkey anti rabbit $\operatorname{lgG}$ see I.c. (2).

Tab. 3. C-reactive protein ILSA flow sheet.

$10 \mu$ sample or standard, $1: 10$ dilution in assay buffer $(0.05 \mathrm{~mol} / 1 \mathrm{Tris}-\mathrm{HCl}$ containing $2.5 \mathrm{~g} / \mathrm{l}$ bovine serum albumin, $\mathrm{pH}$ 7.6)

$200 \mu \mathrm{l}$ assay buffer

1 sheep anti human $\mathrm{C}$-reactive protein coated ball

Incubation $60 \mathrm{~min}$ at $37^{\circ} \mathrm{C}$ in a water bath, followed by $2 \times 5 \mathrm{ml}$ wash with assay buffer

$200 \mu \mathrm{l}$ rabbit anti human C-reactive protein (1:500 dilution)

Incubate and wash as above

$300 \mu \mathrm{l}$ diazoluminol labelled donkey anti rabbit serum (1:60 dilution*)

Incubate as above, wash and transfer balls to measuring cuvette. Load luminometer and proceed as in table 2.

* represents the further dilution of the labelled antibody as prepared in l.c. (2).

SPALT - solid phase antigen luminescence technique

The SPALT principle has been described in detail elsewhere (4, 5 ), and only the variations are briefly described here. The SPALT assay can be set up as either a competitive or sequential assay, depending upon whether the solid phase antigen is added together with the first antibody and sample or after a pre-incubation of first antibody and sample. Tables 4 and 5 show competitive and sequential SPALT assays for caeruloplasmin and thyroxine respectively.

\section{Assay semi-automation}

The assays were originally set up in $55 \times 12 \mathrm{~mm}$ polystyrene tubes which increased the time needed for pipetting and wash steps as each tube had to be processed seperately. To increase throughput and reduce the workload assays were set up in either 20 or 60 well trays (cf. Abbott hepatitis kits). The wash steps were carried out using a Pentawash multiple wash device (Abbott Laboratories) where 5 wells were washed simultaneously with $5 \mathrm{ml}$ wash solution. The antigen-antibody reaction was speeded up by incubating the trays on a horizontal rotator at $180 \mathrm{~min}^{-1}$.
Tab. 4. Caeruloplasmin SPALT flow sheet.

$50 \mu l$ sample or standard, 1:25 dilution in assay buffer (see table 2)

$150 \mu \mathrm{l}$ rabbit anti caeruloplasmin (1:500 dilution)

Incubate at ambient temperature for $10 \mathrm{~min}$ *

1 human caeruloplasmin coated ball

Incubate for $50 \mathrm{~min}$ on horizontal rotator $\left(180 \mathrm{~min}^{-1}\right)$ at ambient temperature

Wash with $2 \times 5 \mathrm{ml} 0.15 \mathrm{~mol} / \mathrm{l} \mathrm{NaCl}$ containing $0.15 \mathrm{ml} / \mathrm{l}$ Tween 20

$200 \mu$ l donkey anti rabbit IgG labelled with $\mathrm{N}$-(4-aminobutyl)-Nethylisoluminol hemisuccinamide $\left(1: 150^{+}\right.$dilution $)$

Incubate for $60 \mathrm{~min}$ on rotator and wash as above.

Transfer balls to measuring cuvettes and proceed as in table 2 .

+ represents dilution of labelled antibody as prepared in l.c. (2).

* this step improved the precision of the assay.

Tab. 5. Thyroxine SPALT flow sheet.

$25 \mu$ l sample or standard

$150 \mu \mathrm{l}$ assay buiffer $(0.05 \mathrm{~mol} / \mathrm{l}$ Tris- $\mathrm{HCl}$ containing

$1.58 \mathrm{mmol} / \mathrm{l}$ 8-anilino-1-naphthalene sulphonic acid

(ammonium salt), $\mathrm{pH} 7.5$

$100 \mu \mathrm{l}$ rabbit anti thyroxine (1:500 dilution)

Incubate for $60 \mathrm{~min}$ at ambient temperature

1 Transferrin-thyroxine coated polystyrene ball*

Incubate as above, but on horizontal rotator and wash with $2 \times 1 \mathrm{ml}$ wash buffer $(0.05 \mathrm{~mol} / \mathrm{l}$ Tris- $\mathrm{HCl}$ containing $0.15 \mathrm{ml} / \mathrm{l}$ Tween $20, \mathrm{pH} 7.5$ )

$300 \mu$ donkey anti rabbit IgG labelled with either pyruvate kinase or diazoluminol ( $1: 50$ dilution)

Incubate for $60 \mathrm{~min}$ on horizontal rotator and wash with $1 \mathrm{ml}$ wash buffer followed by $1 \mathrm{ml} 0.15 \mathrm{~mol} / \mathrm{l} \mathrm{NaCl}$. Transfer balls to measuring cuvettes and proceed with the light initiation step as in table 2 .

* Synthesis of the thyroxine-transferrin conjugate has been described in I.c. (2).

The improvement in precision, shortening of assay time and semiautomation of all methods more than compensated for the additional cost of buying the equipment. Moreover, the trays could be re-used after washing without the precision and accuracy of the assay being influenced.

\section{Results}

Comparison of a CELIA and ILMA for thyroxine binding globulin (TBG)

Figure 1 shows standard curves for a TBG-CELIA and a TBG-ILMA. Table 6 shows the relevant assay and quality control data. The antibody bound to the solid phase was the same in each case as was the label used, in this case diazoluminol. The TBG used for labelling was identical with that used for making up the standards in both assays. 


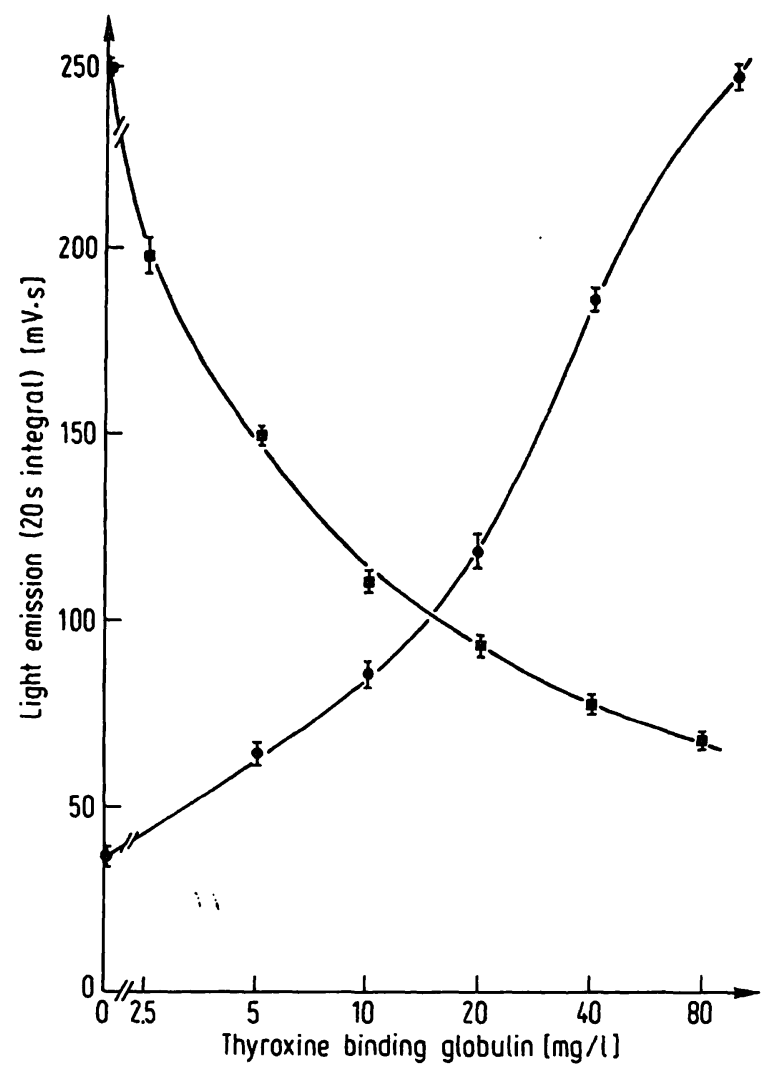

Fig. 1. Comparison between the thyroxine binding globulin CE-

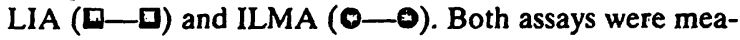
sured on an LKB 1251 luminometer, the ordinate representing the integral of the light curve over 20 seconds. Each standard curve point is shown with the mean and 2 standard deviation ( $95 \%$ confidence-) limits.

Comparison between labelling using ILMA and ILSA for ferritin as examples

Figure 2 shows three standard curves using identical starting reagents. For the ILSA the second antibody (donkey anti-rabbit IgG) was labelled with diazoluminol (2), for the ILMAs both diazoluminol and N(4-aminobutyl)-N-ethyl isoluminol hemisuccinamide were used to label the second anti-ferritin antibody. Table 7 shows relevant data from all three curves, here with special reference to the sensitivity (lowest detectable antigen level).

Comparison of different $\mathrm{pH}$ values to initiate the light reaction using a serum cortisol SPALT as an example

Table 8 shows a comparison between three cortisol SPALT assays set up at the same time with the same reagents. The difference between the assays is that one is oxidised at $\mathrm{pH} 8.6$ to initiate the light reaction, the second with sodium hydroxide, directly after addition, and the third, after the solid phase has been left in contact with sodium hydroxide for $2 \mathrm{~h}$. The assay flow sheet up until the light-reaction step is shown in table 9.
Tab. 6. Comparison of thyroxine binding globulin (TBG) CELIA and ILMA using diazoluminol as label.

\begin{tabular}{|c|c|c|}
\hline $\begin{array}{l}\text { Parameter } \\
\text { Assay type } \\
\text { Sample size }(\mu l) \\
\text { Standard matrix }\end{array}$ & $\begin{array}{l}\text { Assay } 1^{+} \\
\text {CELIA } \\
50 \\
\text { Buffer }\end{array}$ & $\begin{array}{l}\text { Assay } 2 \\
\text { ILMA } \\
1 \text { (20 } \mu \mathrm{l} 1: 20 \\
\text { dilution) } \\
\text { Buffer }\end{array}$ \\
\hline \multicolumn{3}{|l|}{ Standard curve } \\
\hline \multicolumn{3}{|l|}{ Counts ${ }^{++}$} \\
\hline $\begin{array}{l}\text { Zero standard }\left(B_{0}\right) \\
5 \mathrm{mg} / \mathrm{l} \text { standard }\left(B_{5}\right) \\
80 \mathrm{mg} / \mathrm{l} \mathrm{standard}\left(B_{80}\right)\end{array}$ & $\begin{array}{r}250 \\
150 \\
67\end{array}$ & $\begin{array}{r}37 \\
65 \\
245\end{array}$ \\
\hline \multicolumn{3}{|l|}{ Ratios } \\
\hline $\begin{array}{l}\mathrm{B}_{0} / \mathrm{B}_{80} \\
\mathrm{~B}_{5} / \mathrm{B}_{0} \\
\mathrm{~B}_{80} / \mathrm{B}_{0}\end{array}$ & $\begin{array}{l}3.73 * \\
0.60 \\
0.268\end{array}$ & $\begin{array}{l}0.151 \\
1.76 \\
6.62^{*}\end{array}$ \\
\hline \multicolumn{3}{|l|}{$\begin{array}{l}\text { Quality control } \\
\text { Control sera (mg/l)** }\end{array}$} \\
\hline $\begin{array}{l}\text { H1 }(14 \pm 3)(\text { mean } \pm \text { s.d. }) \\
\text { H2 }(26 \pm 5) \\
\text { H3 }(37 \pm 6)\end{array}$ & $\begin{array}{l}\text { above } 80 \\
\text { above } 80 \\
\text { above } 80\end{array}$ & $\begin{array}{l}13.6 \\
27.3 \\
35.9\end{array}$ \\
\hline Correlation data*** & with RIA & \\
\hline $\begin{array}{l}\text { No. of samples } \\
\text { Correlation cofficient } \mathrm{r} \\
\quad \text { Intercept } \mathrm{a}_{\mathrm{yx}}(\mathrm{mg} / \mathrm{l}) \\
\text { Slope } b_{\mathrm{yx}} \\
\text { Range of values used }(\mathrm{mg} / \mathrm{l})\end{array}$ & $\begin{array}{l}- \\
- \\
- \\
-\end{array}$ & $\begin{array}{l}89 \\
0.985 \\
=2.74 \\
0.9 \overline{7} 6 \\
10=4 \overline{3}\end{array}$ \\
\hline
\end{tabular}

+ Both assays were performed simultaneously.

++ Expressed as $\mathrm{mV} \cdot 20 \mathrm{~s}$ (integral)

* These values represent the dynamic range for the CELIA and ILMA respectively.

** The CELIA, although giving a standard curve, was unable to measure serum samples, and was therefore abandonned. Target values in brackets.

*** The correlation coefficient and related data was determined from a comparison with the Henning TBG-RIA, results from 6 assays being used. The RIA values were entered as $x$.

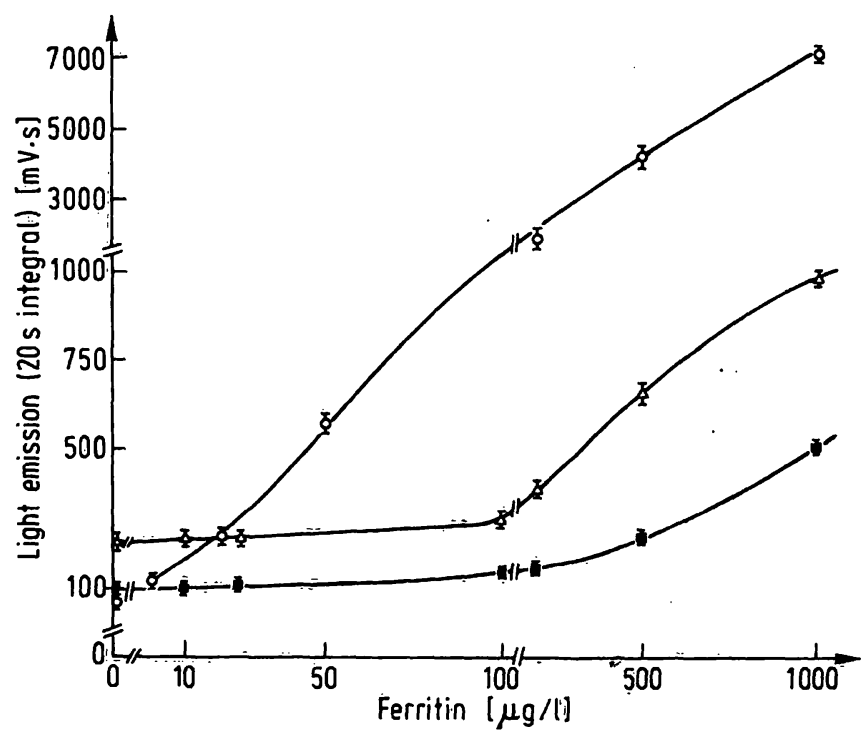

Fig. 2. Comparison of three ferritin assays using diazoluminol - $(\triangle-\triangle$ ILSA; - ILMA) and N-(4-aminobutyl)-Nethyl isoluminol hemisuccinamide (O-O ILMA) labelled antibodies. Please note that the scales are not linear. The symbols and their significance are as in figure 1 . 
Tab. 7. Comparison of ferritin ILMA and ILSA using diazoluminol and $\mathrm{N}$-(4-aminobutyl)- $\mathrm{N}$-ethylisoluminol hemisuccinamide (ABEI-H) as labels - relevant assay data.

\begin{tabular}{lccc}
\hline Parameter & $\begin{array}{c}\text { ILMA-1 } \\
\text { Diazo- } \\
\text { luminol }\end{array}$ & $\begin{array}{c}\text { ILMA-2 } \\
\text { ABEI-H }\end{array}$ & $\begin{array}{c}\text { ILSA } \\
\text { Diazo- } \\
\text { luminol }\end{array}$ \\
\hline Counts $^{+}$ & & & \\
Zero standard $\left(\mathrm{B}_{0}\right)$ & 103 & 78 & 222 \\
$\quad 5 \mu \mathrm{g} / \mathrm{l}$ standard $\left(\mathrm{B}_{5}\right)$ & - & 125 & - \\
$10 \mu \mathrm{g} / \mathrm{l}$ standard $\left(\mathrm{B}_{10}\right)$ & 108 & - & 238 \\
$200 \mu \mathrm{g} / \mathrm{l}$ standard $\left(\mathrm{B}_{200}\right)$ & 15.5 & 1940 & 370 \\
$1000 \mu \mathrm{g} / \mathrm{l}$ standard $\left(\mathrm{B}_{1000}\right)$ & 507 & 421.0 & 965 \\
Ratios of counts & & & \\
$\mathrm{B}_{5} / \mathrm{B}_{0}$ & - & 1.60 & - \\
$\mathrm{B}_{10} / \mathrm{B}_{0}$ & 1.05 & - & 1.07 \\
$\mathrm{~B}_{200} / \mathrm{B}_{0}$ & 1.50 & 24.9 & 1.67 \\
$\mathrm{~B}_{1000} / \mathrm{B}_{0}{ }^{++}$ & 4.92 & 54.0 & 4.35 \\
Spread of counts & & & \\
$\mathrm{B}_{1000}-\mathrm{B}_{0}$ & & 4132 & 743 \\
Sample size $(\mu \mathrm{l})$ & 404 & 20 & 100 \\
Assay time (h) & 100 & 6 & 26 \\
Control serum values $(\mu \mathrm{g} / \mathrm{l})^{* *}$ & & & \\
D4 - target value $16 \pm 1.9$ & 30 & 16.4 & 19.0 \\
D5 - target value $53 \pm 4: 2$ & 55.0 & 48.3 & 52.4 \\
D6 - target value $180 \pm 6$ & 192 & 164 & 177 \\
\hline+ & & & \\
\hline
\end{tabular}

+ Integral over $20 \mathrm{~s}$, given in 1000 "Berthold light units"

++ Expression of the dynamic range of the assay

* Represents the actual spread of counts between the lowest and highest standard.

** Values given as mean \pm 1 standard deviation. The values given are the mean of duplicate values.

Tab. 8. Effect of pH and exposure time to sodium hydroxide on the light emission using the cortisol SPALT as an example.

\begin{tabular}{|c|c|c|c|}
\hline Parameter & $\mathrm{pH} 8^{+}$ & $\begin{array}{l}\mathrm{pH} 13^{+} \\
\text {immediate }\end{array}$ & $\begin{array}{l}\mathrm{pH} 13^{+} \\
\text {after } 2 \mathrm{~h}\end{array}$ \\
\hline $\begin{array}{l}\text { Light emission } \\
\text { of zero standard }\left(B_{0}\right)\end{array}$ & $3294^{*}$ & 5391 & 20444 \\
\hline $\begin{array}{l}\text { Light emission of } \\
\text { unspecific binding (UB) }\end{array}$ & $85^{*}$ & 103 & 441 \\
\hline $\begin{array}{l}\text { Light emission of } \\
2650 \mathrm{nmol} / 1 \text { standard }\left(\mathrm{S}_{2650}\right)\end{array}$ & $837 *$ & 1385 & 6726 \\
\hline Ratio $\mathrm{UB} / \mathrm{B}_{0}$ & 0.03 & 0.02 & 0.02 \\
\hline Ratio $\mathrm{S}_{2650} / \mathrm{B}_{0}$ & 0.25 & 0.26 & 0.33 \\
\hline $50 \%$ intercept $(\mathrm{nmol} / \mathrm{l})$ & 660 & 473 & 908 \\
\hline $\begin{array}{l}\text { Control serum D4 }(\mathrm{nmol} / \mathrm{l})^{++} \\
\text {Control serum D5 } \\
\text { Control serum D6 }\end{array}$ & $\begin{array}{r}154 \\
622 \\
1523\end{array}$ & $\begin{array}{r}132 \\
638 \\
1413\end{array}$ & $\begin{array}{r}143 \\
539 \\
1721\end{array}$ \\
\hline
\end{tabular}

* Results. in 1000 "Berthold Light Units"

+ All assays were set up at the same time. The results in column 2 were obtained when the tubes were processed directly after $\mathrm{NaOH}$ addition, those in column 3 when the light initiation step took place $2 \mathrm{~h}$ after $\mathrm{NaOH}$ addition. The results in column 1 were obtained when $0.5 \mathrm{~mol} / 1$ phosphate buffer replaced the $1 \mathrm{~mol} / \mathrm{l} \mathrm{NaOH}$.

++ Results cxpressed are the mean of duplicate tubes.
Tab. 9. Cortisol SPALT flow sheet.

$10 \mu$ sample or standard

$200 \mu \mathrm{l}$ rabbit anti cortisol, 1:4000 in assay buffer

( $0.1 \mathrm{~mol} / \mathrm{l}$ phosphate containing $0.1 \mathrm{~mol} / \mathrm{l}$ sodium salicylate, pH 7.5)

1 cortisol-3-carboxymethyloxime-ovalbumin coated ball

Incubate on horizontal rotator $\left(180 \mathrm{~min}^{-1}\right)$ for $35 \mathrm{~min}$ at ambient temperature

Wash with $2 \times 5 \mathrm{ml} 0.15 \mathrm{~mol} / \mathrm{l} \mathrm{NaCl}$ containing $0.15 \mathrm{ml} / \mathrm{l}$ Tween 20

$200 \mu \mathrm{l}$ N-(4-aminobutyl)-N-ethylisoluminol hemisuccinamide labelled donkey anti rabbit IgG (1:180 dilution*)

Incubate as above, but for $45 \mathrm{~min}$, wash as above and proceed as described in table 2 for the ball-transfer and light-initiating steps

* See table 4.

Comparison between pyruvate kinase and diazoluminol as label for the second antibody using a thyroxine SPALT'as an example

The assay flow scheme has already been shown in table 5. Figure 3 shows standard curves for both assays, the relevant assay data being shown in table 10 .

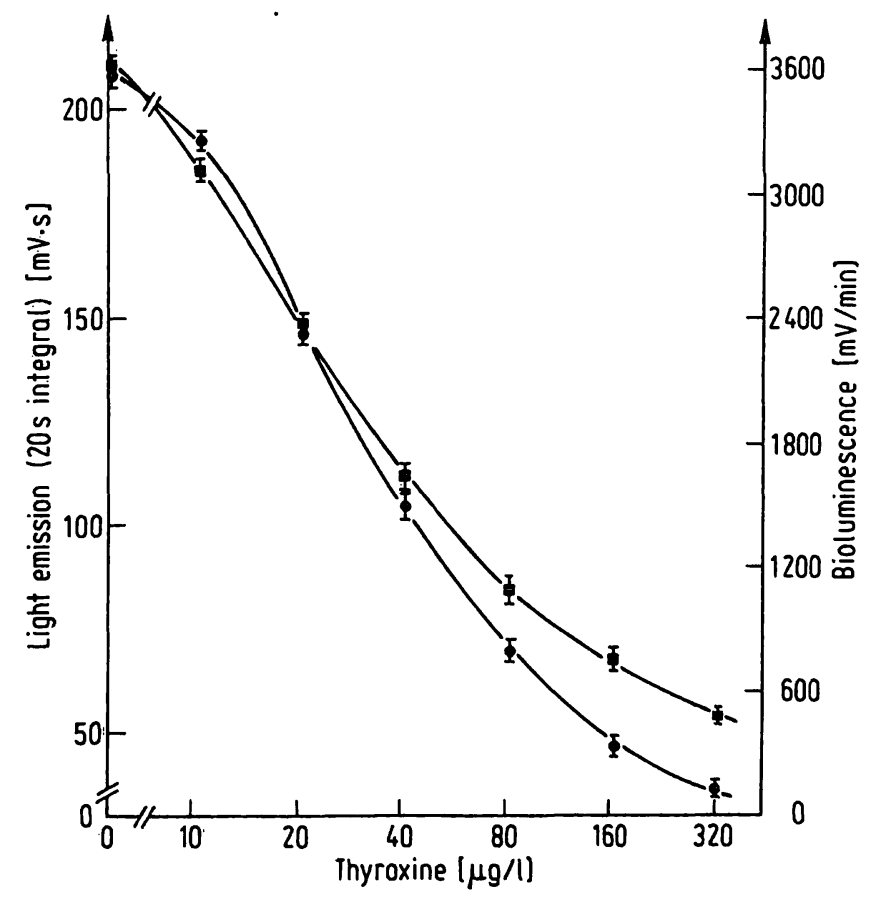

Fig. 3. Comparison of use of a bioluminescent (pyruvate kinase -D) label and a chemiluminescent label in a thyroxine SPALT. Both assays were measured on an LKB 1250 luminometer, the left-hand ordinate showing the chemiluminescent signal as $20 \mathrm{~s}$ integral, the right-hand ordinate the slope of the ATP-generation curve, expressed as $\mathrm{mV}$ / $\min$. 
Tab. 10. Comparison between a chemiluminescent and bioluminescent labelled SPALT assay for serum thyroxine.

\begin{tabular}{|c|c|c|}
\hline Parameter & Assay $1^{*}$ & Assay 2 \\
\hline Label & Diazoluminol & $\begin{array}{l}\text { Pyruvate } \\
\text { kinase }\end{array}$ \\
\hline \multicolumn{3}{|l|}{ Standard curve } \\
\hline \multicolumn{3}{|l|}{ Counts } \\
\hline $\begin{array}{l}\text { Zero standard }\left(\mathrm{B}_{0}\right) \\
12 \mathrm{nmol} / \mathrm{l} \text { standard }\left(\mathrm{B}_{12}\right) \\
410 \mathrm{nmol} / \mathrm{l} \text { standard }\left(\mathrm{B}_{410}\right) \\
\text { Unspecific binding (UB) }\end{array}$ & $\begin{array}{r}240 \\
222 \\
66 \\
31\end{array}$ & $\begin{array}{r}3780 \\
3280 \\
674 \\
202\end{array}$ \\
\hline \multicolumn{3}{|l|}{ Ratios } \\
\hline $\begin{array}{l}\mathrm{UB} / \mathrm{B}_{0} \\
\mathrm{~B}_{12} / \mathrm{B}_{0} \\
\mathrm{~B}_{410} / \mathrm{B}_{0} \\
\mathrm{~B}_{0} / \mathrm{B}_{410^{++}}\end{array}$ & $\begin{array}{l}0.130 \\
0.925 \\
0.275 \\
3.64\end{array}$ & $\begin{array}{l}0.053 \\
0.868 \\
0.178 \\
5.61\end{array}$ \\
\hline \multicolumn{3}{|l|}{ Intercepts (nmol/l) } \\
\hline $\begin{array}{l}80 \% \\
50 \% \\
20 \%\end{array}$ & $\begin{array}{l}21.4 \\
64.8 \\
313\end{array}$ & $\begin{array}{l}23.4 \\
57.4 \\
285\end{array}$ \\
\hline \multicolumn{3}{|l|}{ Quality control } \\
\hline $\begin{array}{l}\text { Serum A }(27 \pm 5) \mathrm{nmol} / \mathrm{I}^{* *} \\
\text { Serum B }(74 \pm 10) \\
\text { Serum C }(166 \pm 16)\end{array}$ & $\begin{array}{c}21.1 \\
81.8 \\
165\end{array}$ & $\begin{array}{r}24.0 \\
71.6 \\
157\end{array}$ \\
\hline
\end{tabular}

+ Counts for Assay $1 \mathrm{mV} \cdot 20 \mathrm{~s}$ (integral), for Assay $2 \mathrm{mV} / \mathrm{min}$ (slope)

++ Expression of the assay dynamic range

* Assays set up at the same time and measured manually on an LKB 1250 Luminometer (see 1.c. (1) and (2))

** Target values \pm 1 standard deviation - results are the mean of duplicate determinations.

Clinical examples of routine luminescence immunoassays - data from a caeruloplasmin SPALT, a $C$ reactive protein ILSA and a ferritin ILMA

Figures 4 and 5 show typical standard curves for caeruloplasmin and C-reactive protein respectively. The label for the caeruloplasmin SPALT was N-(4-aminobutyl)-N-ethyl isoluminol hemisuccinamide, for C-reactive protein, diazoluminol. In both cases, the second antibody was labelled donkey anti-rabbit IgG. Table 11 shows clinical data obtained for different patient groups. The correlation between the ferritin assay here described and the radioimmunoassay used as its predecessor in the routine determination was excellent, $\left(\mathrm{n}=91, \mathrm{r}=0.992, \mathrm{a}_{\mathrm{yx}}=0.071\right.$ and $b_{y x}=0.999$ ) when the same standards were used in each assay. Here the radioimmunoassay values were entered as $x$, those from the ILMA as $y$. The range of the values used for this calculation were $5-570 \mu \mathrm{g} / 1$ for the RIA and 3-567 $\mu \mathrm{g} / \mathrm{l}$ for the ILMA.

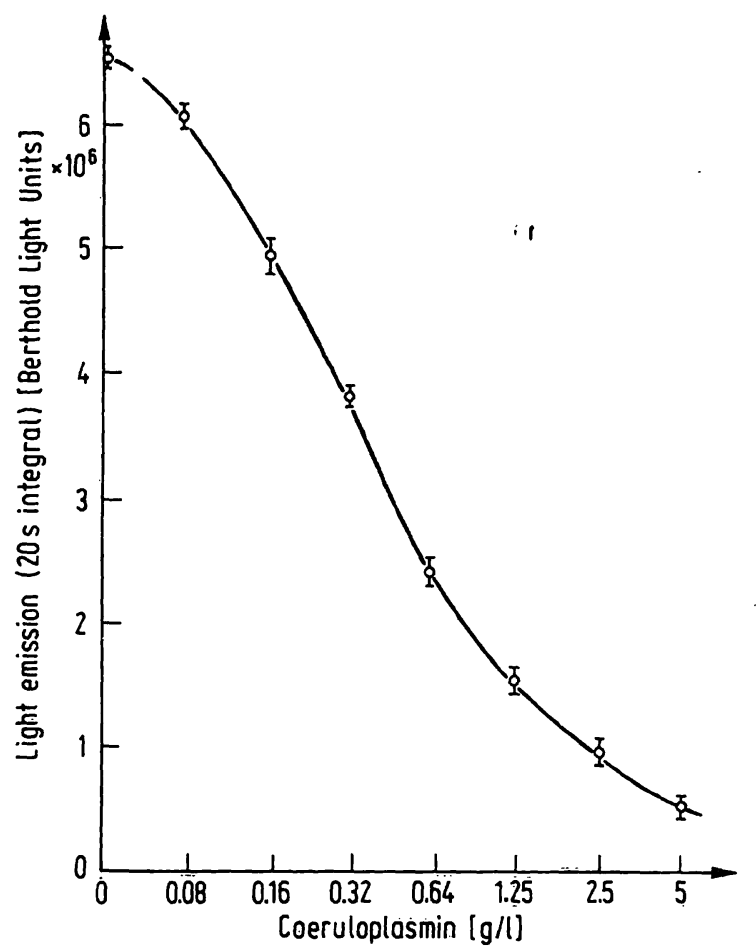

Fig. 4. Caeruloplasmin SPALT measured on the Berthold LB950 luminometer. The ordinate represents the $20 \mathrm{~s}$ integral, expressed here in "Berthold light units" $\times 10^{6}$, as this luminometer employs photon counting techniques rather than the current amplification method used in the LKB instruments.

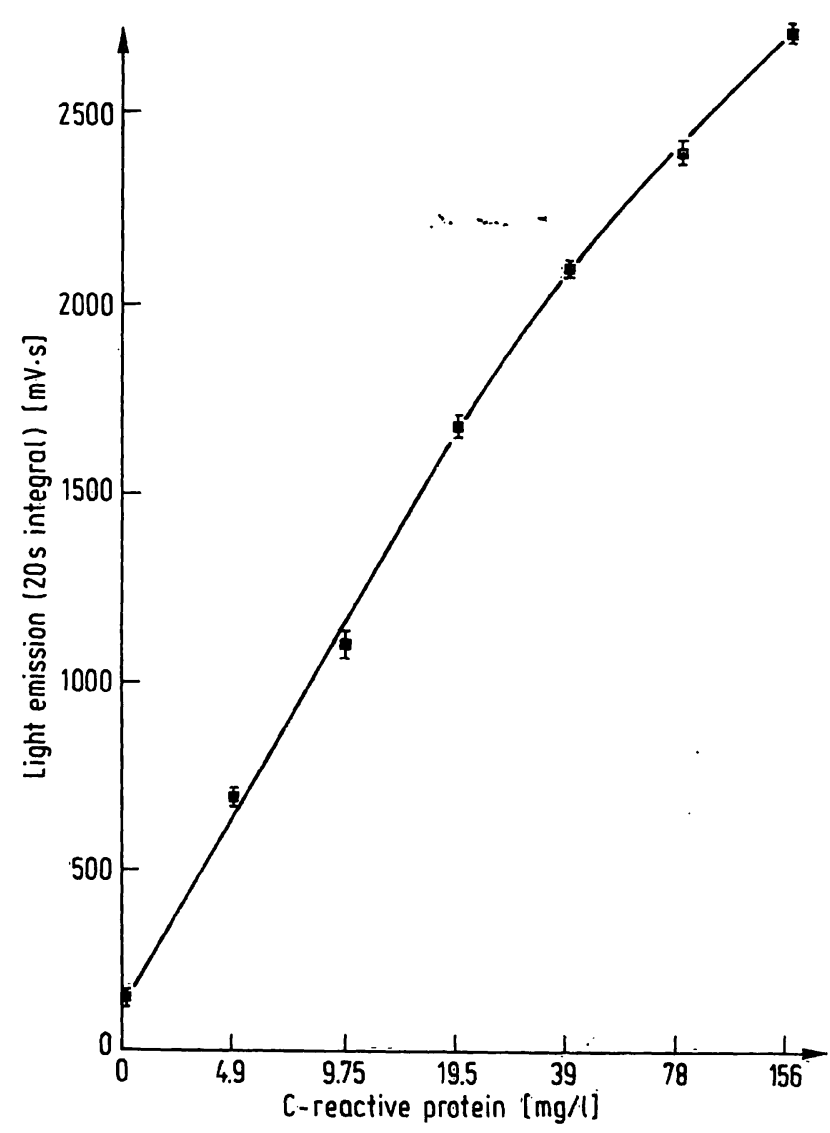

Fig. 5. C-reactive protein ILSA, using a diazoluminol labelled second antibody (donkey anti-rabbit IgG). This assay was measured on an LKB 1251 lyminometer, the ordinate showing the $20 \mathrm{~s}$ integral value. 
Tab. 11. Assay parameters and values from three experimental groups for caeruloplasmin, C-reactive protein and ferritin assays.

\begin{tabular}{llll}
\hline Parameter & $\begin{array}{l}\text { Caerulo- } \\
\text { plasmin }\end{array}$ & $\begin{array}{l}\text { C-reactive } \\
\text { protein }\end{array}$ & Ferritin \\
Assay type & SPALT & ILSA & ILMA \\
Label & ABEI-H & Diazoluminol & ABEI-H \\
Standard matrix & Buffer & Serum & Buffer \\
Standard & Human CP+ & Human CRP+ & Human $\mathrm{LF}^{+}$ \\
\hline
\end{tabular}

\begin{tabular}{|c|c|c|c|}
\hline $\begin{array}{l}\text { Reference range } \\
\text { (serum) }\end{array}$ & $0.15-0.65 \mathrm{~g} / 1$ & under $5 \mathrm{mg} / \mathrm{l}$ & $30-300 \mu \mathrm{g} / \mathrm{I}$ \\
\hline $\begin{array}{l}\text { Assay working } \\
\text { range }^{++}\end{array}$ & $0.15-1.25 \mathrm{~g} / 1$ & $2-160 \mathrm{mg} / \mathrm{l}$ & $5-1000 \mu \mathrm{g} / 1$ \\
\hline $\begin{array}{l}\text { Mean precision } \\
(\%)^{+++}\end{array}$ & $5.8(n=205)$ & $4.2(n=99)$ & $4.3(n=1254)$ \\
\hline $\begin{array}{l}\text { Lower detection } \\
\text { limit }\end{array}$ & $<0.08 \mathrm{~g} / 1$ & $<1 \mathrm{mg} / \mathrm{l}$ & $<2 \mu \mathrm{g} / 1$ \\
\hline \multicolumn{4}{|l|}{$\begin{array}{l}\text { Experimental } \\
\text { groups }\end{array}$} \\
\hline Crohn/Colitis & & & \\
\hline
\end{tabular}

$\begin{array}{llll}\text { Range } & 0.14-0.53 \mathrm{~g} / 1 & 1.72-60.2 \mathrm{mg} / 1 & 2-911 \mu \mathrm{g} / \mathrm{l} \\ \text { Median } & 0.30 \mathrm{~g} / 1 & 22.9 \mathrm{mg} / 1 & 23.8 \mu \mathrm{g} / \mathrm{l} \\ \begin{array}{l}\text { No. of elevated } \\ \text { values }\end{array} & 0 & 18 & 4 \\ \begin{array}{l}\text { No. of reduced } \\ \text { values* }\end{array} & 1 & - & 23 \\ \begin{array}{l}\text { No. of patients } \\ \text { in group }\end{array} & 12 & 21 & 40\end{array}$

Tumour bearers**

\begin{tabular}{|c|c|c|c|}
\hline Range & $0.13-2.34$ & $0.8-139$ & $3-2440$ \\
\hline Median & 0.44 & 11.8 & 152 \\
\hline $\begin{array}{l}\text { No. of elevated } \\
\text { values }\end{array}$ & 12 & 14 & 14 \\
\hline $\begin{array}{l}\text { No. of reduced } \\
\text { values }\end{array}$ & 1 & - & 4 \\
\hline $\begin{array}{l}\text { No. of patients } \\
\text { in group }\end{array}$ & 35 & 18 & 42 \\
\hline \multicolumn{4}{|l|}{$\begin{array}{l}\text { Blood donors = } \\
\text { unselected }\end{array}$} \\
\hline Range & $0.06-1.01$ & $0.5-10.7$ & $5-240$ \\
\hline Median & 0.26 & 0.91 & 58 \\
\hline $\begin{array}{l}\text { No. of elevated } \\
\text { valuẹs }\end{array}$ & 3 & 3 & 0 \\
\hline $\begin{array}{l}\text { No. of reduced } \\
\text { values }\end{array}$ & 4 & - & 16 \\
\hline No. in group & 45 & 64 & 84 \\
\hline
\end{tabular}

$+\mathrm{CP}=$ caeruloplasmin, $\mathrm{CRP}=\mathrm{C}$-reactive protein, $\mathrm{LF}=$ liver ferritin, ABEI-H = N-(4-aminobutyl)-N-ethyl isoluminol hemisuccinamide

++ Range in which the mean precision is under $10 \%$

++ Actual precision within the working range - mean of all patients $(n=\ldots)$

* Values lying below or above the established reference range.

** Pre-operative values - only patients with surgically confirmed tumours used in this analysis.

\section{Discussion}

The aim of this paper has been to put into practice some of the experiments performed in the first two parts of this series $(1,2)$. A comparison of both labels and methods has been made using a wide variety of antigens as ligands. Detailed clinical trials and evaluation results have been avoided, results being limited to a few assays, especially those shown in table 11 .

The future of the luminescence immunoassay lies in its field of application, especially where its role as a practical alternative to routine radioimmunoassays is concerned. The assays presented here represent the whole gamut of molecular size and concentration found in in-vitro clinical chemistry and endocrinology.

The results of the comparison between a CELIA and ILMA using the same label and components (diazoluminol and immobilised sheep anti TBG) shows the relative sensitivity and working range of the two assay types, here for thyroxine binding globulin. The larger working range of the ILMA agrees with the findings of Hunter (6) who compared radioimmunoassays and immunoradiometric assays for sensitivity and working range. The TBG CELIA, although giving a dose response curve when the standards were dissolved in a buffer matrix, was unable to be used for measuring serum samples, where all values lay above the highest standard. The combination of the relatively large sample volume $(50 \mu \mathrm{l})$ and contact between serum and label may be a crucial factor with the CELIA, as the TBG ILMA, where a much smaller sample $(1 \mu \mathrm{l})$ was used, and where serum and label did not come into contact, measured correctly. Similar problems were encountered with a thyroxine CELIA using larger serum volumes $(50 \mu \mathrm{l})$ and lowtiter low affinity antibodies (Gadow, unpublished results).

The comparison between the different labels is well demonstrated in the case of the ferritin assays (table 7, figure 2). Although the detection limits of free diazoluminol and $\mathrm{N}$-(4-aminobutyl)- $\mathrm{N}$-ethyl isoluminol hemisuccinamide were similar (2), the $\mathrm{N}$-(4-aminobutyl)-N-ethyl isoluminol hemisuccinamide label allowed an assay to be developed which was sensitive enough for routine use. This was probably due to the difference in the chemical coupling methods used, the $\mathrm{N}$-(4-aminobutyl)-N-ethyl isoluminol hemisuccinamide active ester being under neutral and mild reaction conditions, the diazo coupling taking place in alkaline solution over a period of several hours. The ferritin assays show the relative performance of ILMA and ILSA using the same label (here diazolu- 
minol). The dynamic range of the $\mathrm{N}$-(4-aminobutyl)$\mathrm{N}$-ethyl isoluminol hemisuccinamide labelled ferritin ILMA is far greater than that using diazoluminol as label. This is reflected in the ratio between the number of counts in the highest standard and those in the zero standard, (see tab. 7). This ratio was 54:1 for $\mathrm{N}$-(4-aminobutyl)- $\mathrm{N}$-ethyl isoluminol hemisuccinamide labelled anti ferritin and only 4.9:1 for diazoluminol labelled anti ferritin.

Various conditions have been described for the optimal conditions for light emission which range from initiation at $\mathrm{pH} 8-9$ (7) via $\mathrm{pH} 13$ (4) to initiation after standing in alkaline solution for several minutes (8) to a few hours (Kohen, personal communication). The cortisol SPALT (see tab. 8 and 9) was used to compare the effect of $\mathrm{pH}$ and alkaline incubation on the light output. Although the signal increases between $\mathrm{pH} 8$ and $\mathrm{pH} 13$ as well as between pH 13 when measured immediately and after $2 \mathrm{~h}$ standing in sodium hydroxide, the signal to noise ratio, expressed in terms of the zero standard $\left(B_{0}\right)$ and unspecific binding (UB) increased only slightly.

The dynamic range of the assay, expressed as the light signal given by the zero standard and that given by the highest standard, remained almost unchanged between $\mathrm{pH} 8$ and $\mathrm{pH} 13$, and was noticably reduced after prolonged alkaline incubation before light initiation.

The values of the control sera lay within the expected limits for all assays.

The thyroxine SPALT was used to demonstrate the use of bioluminescent and chemiluminescent labels. The bioluminescent SPALT had a larger dynamic range when compared with the diazoluminol labelled assay, and was potentially more sensitive, as can be seen from the intercept values (tab. 10). Both assays measured correctly in terms of the control sera. Replacement of the diazoluminol labelled second antibody by one labelled with $\mathrm{N}$-(4-aminobutyl)- $\mathrm{N}$-ethyl isoluminol hemisuccinamide gave rise to a similar increase in the dynamic range as seen in the ferritin ILMA, so that for the routine assay, $\mathrm{N}$-(4-aminobutyl)- $\mathrm{N}$-ethyl isoluminol hemisuccinamide was chosen as label.

As stated above, the proof of the assays is in their clinical routine application and examples have been presented for ferritin, C-reactive protein and caeruloplasmin, all of which are the only routine assay for these components. The results shown are taken from projects on patients with tumours and with Crohn's disease or ulcerative colitis (see tab. 11). The screen= ing of blood donors is part of an ongoing routine procedure, especially upon new and regular donors.

The mean precision within the working range, here derived from compound precision profiles, was acceptable and comparable with commercial tests. A further advantage of these tests was their suitability for paediatric use, the largest sample volume being $20 \mu l$ for ferritin.

One thing became clear when working with immobilised antibodies, and that was the necessity for partial purification of the native antisera before coupling to the solid phase. This was effected by precipitation of the $\gamma$-globulin fraction with $200 \mathrm{~g} / \mathrm{l}$ polyethylene glycol $\left(M_{\mathrm{r}} 6000\right)$ with resolution of the precipitate in $0.02 \mathrm{~mol} / 1$ phosphate buffer, $\mathrm{pH}$ 8. Subsequent passage over a DEAE-cellulose column was sufficient to give a product with acceptable purity.

To conclude, it has been shown that the application of luminescence immunoassays in routine in-vitro diagnosis is now possible, although the acceptance of such assays still depends upon the commercialisation of the methods.

\section{Acknowledgements}

The authors wish to thank Frau Jutta Jäger för technical assistence.

\section{References}

1. Wood, W. G. \& Gadow, A. (1983) J. Clin. Chem. Clin. Biochem. 21, 789-797.

2. Gadow, A., Fricke, H. \& Wood, W. G. (1984) J. Clin. Chem. Clin. Biochem. 22, 337-347.

3. Miles, L. E. M. \& Hales, C. N. (1968) Nature $219,186$.

4: Strasburger, C. J., Fricke, H. \& Wood, W. G. (1982) In: Radioimmunoassay and related procedures in medicine 1982, IAEA, Vienna, pp. 757-777.

5. Wood, W. G., Fricke, H., von Klitzing, L., Strasburger, C. J. \& Scriba, P. C. (1982) J. Clin. Chem. Clin. Biochem. 20, 825831.

6. Hunter, W. M. (1982) In: Radioimmunoassay and related procedure in medicine 1982, IAEA, Vienna, pp. 3-21.

7. Kohen, F., Kim, J. B. \& Lindner, H. R. (1981) In: Bioluminescence and chemiluminescence, basic chemistry and analytical applications (DeLuca, Marlene A., McElroy, W. D., eds.) Academic Press, New York, pp. 357-364.

8. Strasburger, C. J., Fricke, H. \& Wood, W. G. (1982) Fresenius Z. Anal. Chem. 311, 351-352.

Priv.-Doz. Dr. W. G. Wood

Klinische Laboratorien

Klinik für Innere Medizin

Medizinische Hochschule Lübeck

Ratzeburger Allee 160

D-2400 Lübeck 1 